\title{
Pengembangan Aplikasi Android E-Initiative Patriot Pangan sebagai Platform Crowdfunding Kebutuhan Balita Menggunakan REST API
}

\section{Development of Android E-Initiative Patriot Pangan Application as a Crowdfunding Platform for Toddler Needs Using REST API}

\author{
RYAN AZRIAN SYACH ${ }^{1 *}$, DEAN APRIANA RAMADHAN ${ }^{1}$
}

\begin{abstract}
Abstrak
Masa balita merupakan masa keemasan dalam seorang anak. Saat ini angka balita kekurangan gizi mencapai 17.8\%. Jumlah penduduk Indonesia mencapai 261.9 Juta jiwa. Dengan tingginya jumlah penduduk Indonesia sehingga memungkinkan untuk berkolaborasi dalam membantu menekan angka kekurangan gizi. Jika masyarakat bersama-sama memberikan bantuan pangan kepada balita kekurangan gizi maka akan membantu menekan angka kekurangan gizi. Memberikan bantuan secara bersama-sama disebut crowdfunding. Crowdfunding umumnya disediakan dalam bentuk platform sebagai tempat bertemunya pendonor dan pemilik proyek. Oleh karena itu, penelitian ini dilakukan untuk mengembangkan aplikasi crowdfunding kebutuhan balita dalam bentuk mobile apps. Pengembangan dilakukan menggunakan metode Scrum dengan 5 sprint. Pengembangan menggunakan REST API sebagai antarmuka untuk komunikasi data antara server dan mobile apps. Penelitian ini mengembangkan aplikasi dalam bentuk Android. Seluruh masyarakat dapat menggunakan aplikasi ini. Jumlah product backlog yang dikerjakan pada penelitian ini adalah 19 items. Penelitian ini berhasil mengembangkan seluruh product backlog. Fungsi utama yang dikerjakan meliputi buat campaign, berdonasi uang/barang, dan membagikan campaign di media sosial.
\end{abstract}

Kata Kunci: android, crowdfunding, gizi, mobile apps, REST API.

\begin{abstract}
Toddler age is a gold age for a child. Currently the number of malnourished children is reaching $17.8 \%$. The number of Indonesian populations reach 261.9 Million. With a high population, Indonesia is very likely to make a collaboration in helping to reduce malnutrition. If the community together provides food assistance to malnourished children, it will help reduce the number of malnutrition. Fund a project together is called crowdfunding. Crowdfunding is generally provided as a platform for place to meet donors and project owner. Currently 9 million children experience malnutrition. This research was conducted to develop crowdfunding applications for toddlers' needs in the form of mobile apps. Development is done using Scrum method with five sprints. Development is using the REST API as an interface for data communication between servers and mobile apps. This research was developed in the form of android. The total of product backlog that done on this research is 19 items. This research is successfully developed all product backlog. The Main function being work out is making campaign, donating money/stuff, and sharing campaign in social media.
\end{abstract}

Keywords: android, crowdfunding, nutrition, mobile apps, REST API.

\section{PENDAHULUAN}

Sustainable Development Goals (SDGs) merupakan kesepakatan pembangunan bersama untuk mendorong pembangunan sosial, ekonomi dan lingkungan hidup. Dalam pelaksanaannya, untuk mencapai hal tersebut maka perlu adanya kerjasama beberapa sektor

\footnotetext{
${ }^{1}$ Departemen Ilmu Komputer, Fakultas Matematika dan Ilmu Pengetahuan Alam, Institut Pertanian Bogor, Jl. Meranti Wing 20 lv 5-6, Kampus IPB Dramaga, Dramaga, Bogor 16680;

*Penulis korespondensi : ryan_azrian@apps.ipb.ac.id
} 
sehingga tidak hanya dibebankan kepada pemerintah (Sachs 2012). Salah satu tujuan dari SDGs adalah mengakhiri kelaparan, mencapai ketahanan pangan dan perbaikan nutrisi. Namun menurut Pemantauan Status Gizi yang dilakukan oleh Kemenkes (2018) sebanyak 17.8\% balita di Indonesia mengalami underweight/berat badan kurang/gizi kurang. Padahal masa balita merupakan masa keemasan bagi seorang anak untuk tumbuh. Menurut (BPS 2018) jumlah penduduk Indonesia mencapai 261.9 jiwa. Dengan tingginya jumlah penduduk Indonesia maka sangat memungkinkan untuk melakukan kolaborasi dalam melakukan sesuatu.

Untuk membantu memenuhi kebutuhan balita tersebut tentunya akan sangat membantu bila masyarakat, organisasi sosial, dan corporate social responsibility (CSR) dapat berpartisipasi membantu memberikan bantuan secara langsung. Pendanaan secara bersamasama seperti ini disebut sebagai crowdfunding. Secara garis besar, crowdfunding merupakan suatu cara alternatif untuk mendanai sebuah proyek, oleh para donatur yang tersebar secara luas dengan kotribusi keuangan yang relatif kecil untuk menyukseskan suatu proyek yang imbalannya dapat berbentuk secara fisik, keuangan maupun penghargaan sosial (Alegre dan Moleskis 2016). Menurut Massolution (2015), platform crowdfunding terbagi atas 4 tipe yaitu equity-based, lending-based, reward-based, dan donation-based. Pembagian tersebut berdasarkan reward yang didapatkan oleh donatur setelah mendonasikan uangnya. Sistem ini memungkinkan orang untuk melakukan penggalangan dana untuk proyek komersial maupun untuk kepentingan sosial. Tentunya akan sangat membantu untuk menekan angka kekurangan gizi pada balita jika masyarakat dapat secara langsung membantu kebutuhan bagi balita yang kurang mampu.

Umumnya, crowdfunding disediakan dalam sebuah platform yang menjadi tempat bertemunya antara project owner dengan masyarakat yang memberikan dana. Salah satu contoh platform crowdfunding adalah Kickstarter. Kickstarter yang diklaim sebagai platform crowdfunding terbesar di dunia telah didanai oleh lebih dari 19 juta orang untuk 191,810 proyek kreatif sejak diluncurkan pada tahun 2009 (Kickstarter 2020). Misi dari perusahaan ini adalah membantu mewujudkan proyek-proyek kreatif. Kickstarter membantu para seniman, musisi, pembuat film, desainer, dan pembuat konten untuk menemukan sumber daya yang dibutuhkan sehingga dapat mewujudkan ide-ide mereka. Menariknya para pemberi sumbangan pada proyek-proyek Kickstarter ditawari hadiah atas sumbangan yang telah mereka berikan. Pada tahun 2012 salah satu campaign di Kickstarter mencoba mengumpulkan dana sebanyak \$25,000 untuk membantu memperbaiki gizi di Walker Jones Education Campus, DC (The Atlantic 2012).

Contoh lain platform crowdfunding adalah GoFund yang berbasis web dan aplikasi Facebook. Dalam aplikasi tersebut, pengguna dapat ikut berkontribusi dalam campaign yang tersedia. Selain itu, pengguna yang sudah terdaftar juga dapat membuat campaign untuk mengumpulkan dana dalam rangka mencapai kesuksesan proyeknya. Aplikasi ini dikembangkan menggunakan Kendo UI untuk framework antarmukanya dan Slim Framework untuk pengembangan application programming interface (API). Aplikasi ini menggunakan Facebook Application untuk meningkatkan publikasi campaign (Rosalina et al 2015).

Untuk itu, sebuah platform yang mendukung proses crowdfunding tersebut diperlukan. Penelitian sebelumnya telah berhasil mengembangkan sistem Patriot Pangan yang merupakan aplikasi yang menggunakan partisipasi masyarakat untuk sistem peringatan dini dalam hal kerawanan pangan (Panatagama et al. 2019; Asfarian et al. 2020). Menurut penelitian AAPJI (2017) pengguna internet di Indonesia sebanyak 143.26 juta dan $44.16 \%$ mengakses melalui smartphone. Maka dari itu, penelitian ini dimaksudkan untuk mengembangkan aplikasi Android crowdfunding untuk memenuhi kebutuhan balita. Hasil dari pelaporan keluarga miskin pada aplikasi Patriot Pangan akan dijadikan sebagai campaign pada aplikasi crowdfunding yang akan dikembangkan. Aplikasi ini bertujuan sebagai jembatan penghubung antara pendonor (masyarakat, CSR, dan organisasi sosial) dengan para penerima bantuan. Dalam aplikasi ini pendonor dapat memberikan bantuannya dalam bentuk pangan (susu, makanan sehat, dan 
suplemen tumbuh kembang) ataupun dalam bentuk uang. Penelitian ini mengembangkan aplikasi Android E-Initiative Patriot Pangan sebagai platform crowdfunding kebutuhan balita.

\section{METODE}

\section{Ruang Lingkup}

Lingkup dari penelitian ini, yaitu:

1 Hasil pengembangan sistem tidak diuji secara langsung kepada pengguna sebenarnya.

2 Pengembangan aplikasi hanya terbatas proses crowdfunding.

3 Pengembangan menggunakan hasil dari analisis penelitian lain dengan topik terkait.

4 Barang yang disumbangkan hanya dapat berupa barang kebutuhan balita atau uang tunai.

\section{Arsitektur Sistem}

Sistem Patriot Pangan dibagi menjadi backend, frontend, dan mobile. Penelitian ini hanya berfokus pada pengembangan aplikasi Android crowdfunding. Pengembangan aplikasi Android e-participation dilakukan oleh Maulana (2019), sedangkan pengembangan web admin dilakukan oleh Prakoso (2019) dengan menggunakan Vue.Js. Pada sisi backend dilakukan pengembangan menggunakan Node.Js oleh Firdaus (2019). Pertukaran informasi antara backend dan mobile menggunakan API. API merupakan antarmuka yang menghubungkan antara komputer dan server untuk mengakses data dan fungsi. API digunakan untuk pertukaran informasi (Massé 2012). Selain itu analisis dan perancangan basis data dilakukan oleh Ramadhan (2019) dengan menggunakan MongoDB.

\section{Tahapan Penelitian}

Metode pengembangan yang digunakan dalam penelitian ini adalah Scrum. Menurut Rising dan Janoff (2000), Scrum merupakan metode pengembangan software yang secara bertahap mengembangkan sebuah perangkat lunak pada lingkungan yang kompleks. Scrum membagi peranan dalam metodenya menjadi 3 yaitu product owner, scrum master dan tim pengembang (Schwaber dan Sutherlad 2017). Tahapan kerja Scrum diawali dengan sprint planning meeting yang dilakukan pada awal sprint, kemudian dilanjutkan dengan daily scrum yang merupakan tahapan pembuatan kode program dalam penelitian ini, di akhir sprint dilakukan sprint review meeting dan sprint retrospective (Pressman 2010).

\section{Product Backlog}

Seluruh daftar fungsi tersebut dimasukan ke dalam product backlog. Pada penelitian ini product backlog dibuat berdasarkan hasil diskusi yang melibatkan seluruh tim Scrum baik product owner, scrum master, maupun tim pengembang. Penentuan product backlog dilakukan dengan brainstorming dengan seluruh aktor Scrum.

\section{Sprint Planning Meeting}

Product owner menentukan prioritas fungsi yang akan dikerjakan terlebih dahulu. Kemudian tim pengembang memilih task yang tersedia dalam product backlog dalam mengembangkan aplikasi Patriot Pangan. Product backlog yang diambil dalam penelitian ini hanyalah task dalam pengembangan aplikasi Android crowdfunding Patriot Pangan untuk kebutuhan balita. Kemudian, product backlog yang diambil akan dimasukan dalam sprint backlog.

\section{Daily Scrum Meeting}

Pada tahapan ini, implementasi atau pengembangan terhadap daftar fungsi yang terdapat pada product backlog dilakukan. Pengembangan dilakukan menggunakan Android Studio 
dengan bahasa pemrograman Java. Dalam daily scrum juga dilakukan daily scrum meeting yang dipimpin oleh scrum master untuk memantau kinerja anggota tim.

\section{Sprint Review Meeting}

Sprint Review dilakukan setelah tim pengembang Patriot Pangan selesai mengerjakan satu sprint. Dalam tahapan ini tim pengembang memaparkan dan mendemonstrasikan task yang telah dikerjakan selama satu sprint. Selain itu, tim pengembang juga menyampaikan kendala yang dihadapi dalam mengerjakan task-task saat sprint berlangsung.

\section{Sprint Retrospective}

Setelah dilakukan sprint review, scrum master melakukan evaluasi terhadap task telah dikerjakan oleh tim pengembang Patriot Pangan selama satu sprint. Dalam tahapan ini scrum master juga memberikan penilaian terhadap task yang telah dikerjakan.

\section{HASIL DAN PEMBAHASAN}

\section{Library Android Studio}

Beberapa Library Android Studio yang digunakan untuk pengembangan ini adalah OAuth2 Library Ver. 2.4.2, Volley Ver. 1.1.1, Glide Ver. 4.8.0, Glide Ver. 4.8.0, ZXing ("Zebra Crossing") barcode scanning library for Java Ver. 3.2.1, Gotev Upload Service Ver. 3.4.2, Socket.IO Ver. 0.3.0, dan SublimePicker Library Ver. 2.1.1.

\section{Design Pattern}

Arsitektur pengembangan yang digunakan dalam pengembangan Android ini adalah Model View Controller (MVC). Arsitektur MVC memisahkan antara data (Model), tampilan (View), dan pemrosesannya (Controller). Arsitektur MVC dipilih karena sesuai dengan pengembangan aplikasi Android pada umumnya yaitu memisahkan antara business logic dan presentation logic (Veit dan Hermann 2003). Salah satu contoh implementasi dalam penelitian ini adalah pada modul tambah campaign yang dibagi atas 3 class yaitu AddCampaign.java dan AddCampaign.xml sebagai view, CampaignModel.java sebagai model yang menyimpan data dan AddCampaignController.java sebagai controller yang merupakan perantara interaksi antara view dengan model. Gambar 1 menampilkan ilustrasi MVC pada modul campaign.

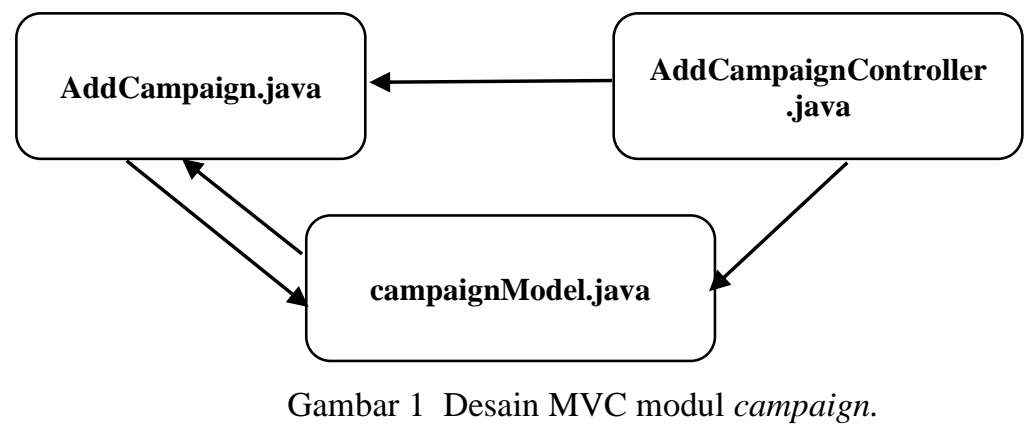

\section{Product Backlog}

Sistem Patriot Pangan dikembangkan berdasarkan product backlog aplikasi E-Initiative yang dibuat oleh product owner. Product backlog tersebut dibuat oleh product owner pada penelitian Panatagama (2019). Dalam penelitian ini product backlog tidak ditentukan sebelum pengembangan dimulai, namun ditentukan saat sprint planning meeting pada awal sprint yang nantinya disebut sebagai sprint backlog. 


\section{Sprint 1}

Sprint Planning Meeting

Product owner menyampaikan secara detail tujuan dan deskripsi dari setiap product backlog. Di sini dihasilkan product backlog yang akan dikembangkan selama Sprint 1. Product backlog yang telah ditentukan untuk dikerjakan adalah fungsi autentikasi, fungsi melihat data diri, fungsi mengubah data diri dan notifikasi bagi pengguna yang belum mengunggah foto diri. Semua ini selanjutnya disebut sebagai sprint backlog.

\section{Daily Scrum}

Pada Sprint 1 dilakukan pengembangan fungsi autentikasi menggunakan google account. Fungsi autentikasi terdiri atas fungsi login dan fungsi register. Fungsi autentikasi akan memeriksa email pengguna melalui token google account kemudian akan dicocokan dengan data di database. Apabila terdapat data yang cocok maka pengguna diizinkan untuk masuk, jika tidak pengguna akan diarahkan ke halaman register untuk mendaftarkan email dan data dirinya kedalam aplikasi. Kemudian juga dikembangkan halaman profil pada aplikasi. Pada halaman profil tersedia data diri pengguna beserta foto profil pengguna dan pengaturan untuk menerima notifikasi atau tidak. Jika pengguna belum mengunggah foto profilnya maka saat pengguna membuka halaman profil akan diberi notifikasi. Pada halaman ubah data diri pengguna, selain dapat mengubah data dirinya pengguna juga dapat mengubah foto profilnya.

\section{Sprint Review Meeting}

Dilakukan pengujian blackbox testing terhadap fungsi-fungsi yang sudah dikembangkan. Pengujian dilakukan terhadap fungsi autentikasi, profil dan ubah profil. Product owner menyetujui semua hasil pengujian dan tidak ada perubahan pada product backlog.

\section{Sprint Retrospective}

Pada Sprint 1 terdapat 6 product backlog yang berhasil dikembangkan sehingga masih terdapat 13 product backlog yang tersisa dan akan didiskusikan pada Sprint Planning Meeting selanjutnya mengenai Product Backlog yang akan dikerjakan. Tidak terdapat masalah pada Sprint 1.

\section{Sprint 2}

\section{Sprint Planning Meeting}

Pada Sprint 2 dipilih sebanyak 6 item yang akan dikerjakan pada Sprint 2. Keenam item yang akan dikerjakan adalah fungsi verifikasi pengguna, tambah campaign oleh pengguna yang sudah diverifikasi, list campaign yang berhasil ditambahkan, lihat detail list campaign, melihat campaign yang sudah diverifikasi, dan fungsi untuk trigger notifikasi jika belum melakukan verifikasi. Pembuatan kode program dilakukan dengan melakukan slicing mockup berdasarkan UI dari penelitian Putra (2020), kemudian selanjutnya dilakukan integrasi dengan backend berdasarkan API yang telah dihasilkan pada penelitian Firdaus (2019). Potongan use case diagram fungsi yang akan dikerjakan selama Sprint 2 dapat dilihat pada Gambar 2.

\section{Daily Scrum}

Dikembangkan fungsi proses pembuatan campaign yang hanya dapat dilakukan oleh pengguna yang sudah melakukan verifikasi. Sehingga sebelum dapat melakukan pembuatan campaign, pengguna harus melakukan verifikasi terlebih dahulu. Analisis proses pembuatan campaign dilakukan pada penelitian Panatagama (2019). Potongan class diagram modul campaign dapat dilihat pada Gambar 3. Setiap campaign memiliki banyak update campaign, sedangkan tiap update campaign hanya memiliki satu campaign. Kemudian hasil analisis tersebut diterjemahkan dalam bentuk kode untuk melakukan posting kepada API Buat 
Campaign yang dapat dilihat Gambar 4. Sehingga tampilan modul pembuatan campaign dapat dilihat pada Gambar 5. Fungsi selanjutnya yang dikembangkan adalah melihat list campaign yang telah dibuat oleh pengguna.

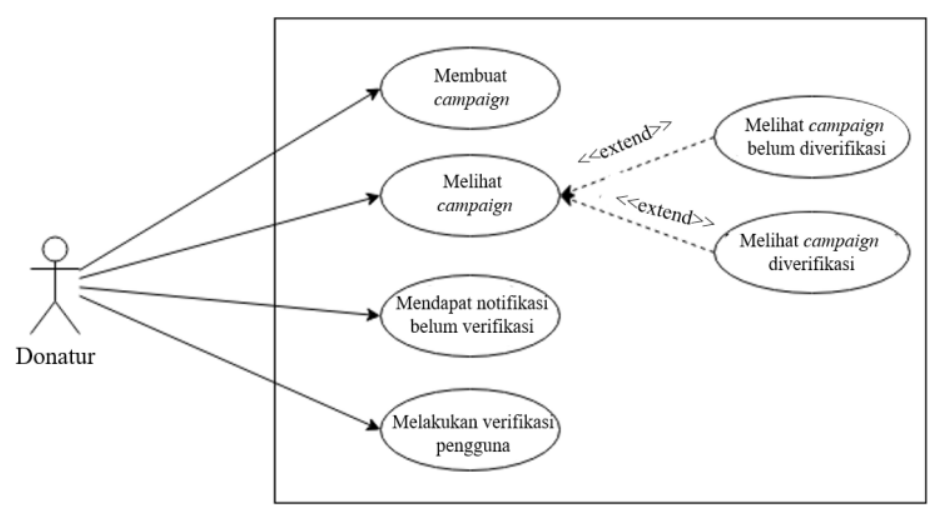

Gambar 2 Use case diagram fungsi Sprint 2.

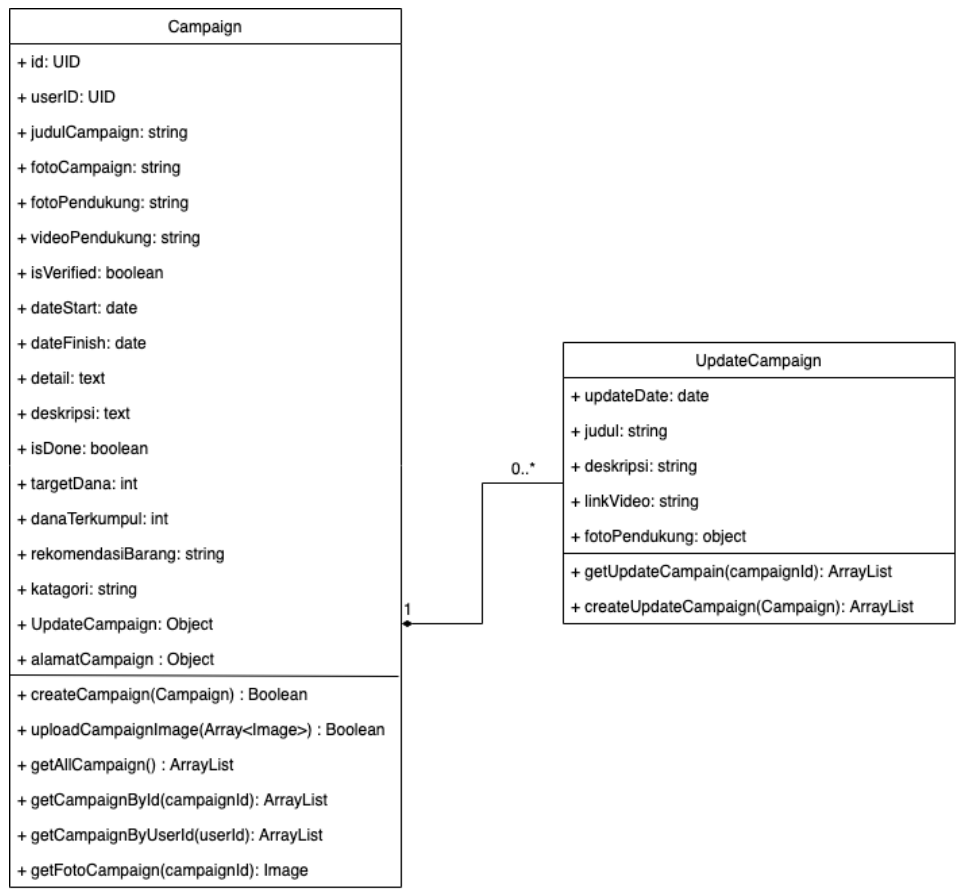

Gambar 3 Potongan class diagram modul campaign.

List campaign dibagi atas campaign yang belum diverifikasi oleh admin dan campaign yang sudah berhasil diverifikasi oleh admin dan telah muncul pada halaman utama aplikasi $E$ Initiative. Pada Sprint 2 juga dikembangkan fungsi untuk melihat list campaign yang sudah diverifikasi oleh admin. Campaign-campaign ini merupakan campaign yang akan tampil di seluruh pengguna yang nantinya dapat melakukan donasi terhadap campaign-campaign ini. Selain itu pada Sprint 2 juga dikembangkan tampilan untuk melihat detail campaign bagi pemilik campaign. Fungsi terakhir yang dikembangkan pada Sprint 2 adalah menampilkan notifikasi yang akan muncul ketika pengguna belum melakukan verifikasi terhadap akunnya atau verifikasinya ditolak oleh admin. Notifikasi ini akan muncul ketika pengguna masuk ke dalam halaman user profile.

\section{Sprint Review Meeting}

Dilakukan pengujian terhadap fungsi-fungsi yang telah dikembangkan pada Sprint 2 dengan menggunakan blackbox testing. Fungsi-fungsi yang diuji meliputi buat campaign, lihat campaign, verifikasi pengguna, dan notifikasi pengguna yang belum verifikasi. Selanjutnya 
product owner menginginkan perubahan pada tampilan detail campaign yang sudah diverifikasi. Sebelumnya pada tampilan tersebut hanya menampilkan detail mengenai campaign tersebut, namun product owner ingin menambahkan tabs untuk tampilan list donatur yang berkontribusi dan list riwayat update yang dilakukan oleh pemilik campaign. Sehingga donatur dapat mengetahui sejauh mana campaign tersebut telah berjalan. Selebihnya product owner menerima hasil dari pengujian fungsi-fungsi yang telah dikerjakan.

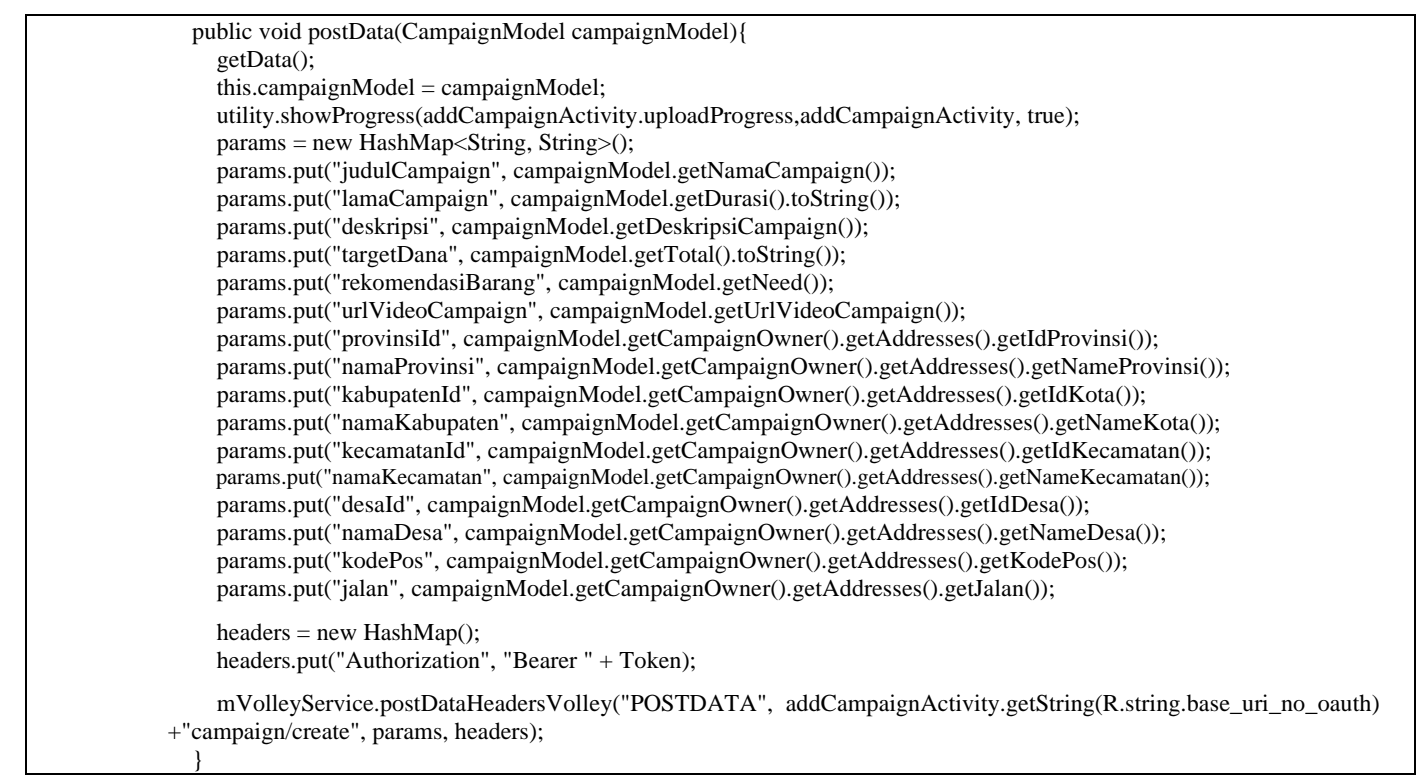

Gambar 4 Potongan kode Post campaign.

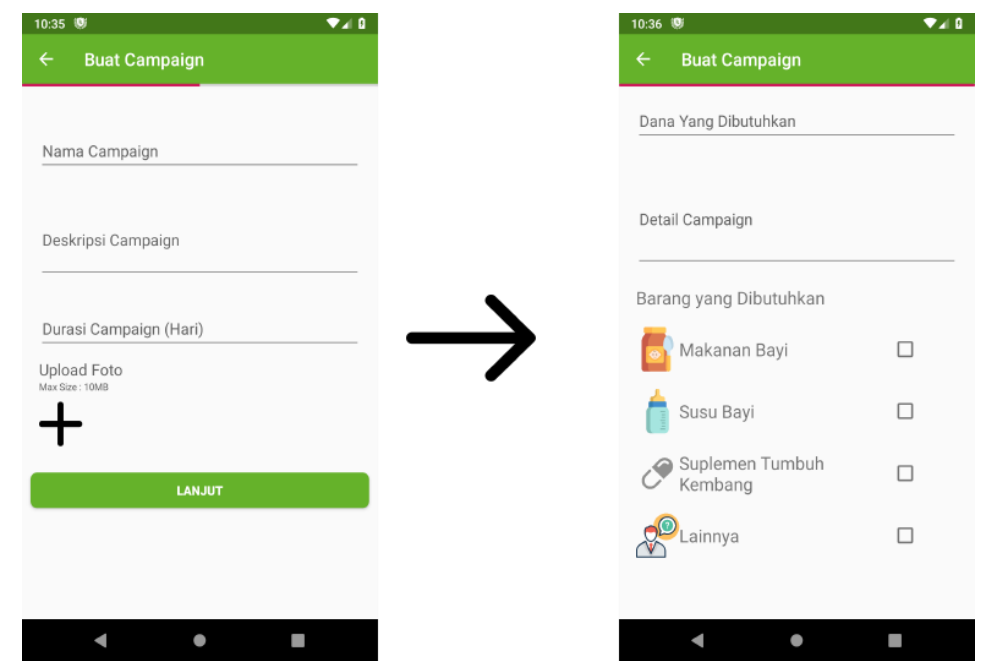

Gambar 5 Tampilan proses pembuatan campaign.

\section{Sprint Retrospective}

Fungsi-fungsi dari product backlog yang dikerjakan pada Sprint 2 sebanyak 6 fungsi. Semua fungsi berhasil dikerjakan dan dapat masuk ke tahapan testing kecuali fungsi detail campaign yang terverifikasi. Tidak terdapat masalah pada Sprint 2.

\section{Sprint 3}

\section{Sprint Planning Meeting}

Sprint backlog yang akan dikerjakan pada Sprint 3 meliputi fungsi donasi, lihat riwayat sumbangan pengguna, dan fungsi untuk membagikan campaign melalui media sosial. Pembuatan kode program dilakukan dengan melakukan slicing tampilan pada Android 
berdasarkan UI dari hasil penelitian yang dilakukan oleh Putra (2020). Setelah pembuatan tampilan selesai, maka dilakukan integrasi dengan backend berdasarkan API yang telah dihasilkan pada penelitian Firdaus (2019).

\section{Daily Scrum}

Fungsi pertama yang dikerjakan adalah fungsi donasi. Potongan class diagram proses donasi dapat dilihat pada Gambar 6. Jika memilih donasi dalam bentuk uang maka pengguna akan diarahkan untuk memilih metode transfer. Kemudian setelah memilih metode transfer maka akan muncul tampilan untuk melakukan transfer kepada rekening yang telah dipilih. Namun, jika pengguna memilih untuk mendonasikan barang maka pengguna akan diarahkan untuk memasukan barang yang didonasikan dan jumlahnya, selanjutnya sistem akan membangkitkan $Q R$ Code untuk nantinya ditempelkan pada barang yang akan dikirim. Tampilan proses donasi barang ditampilkan pada Gambar 7. Fungsi selanjutnya yang dikembangkan pada Sprint 3 adalah fungsi bagi pengguna untuk melihat donasi yang sudah disumbangkan. Selain itu juga dikembangkan halaman untuk melihat informasi campaign yang didonasikan oleh pengguna. Fungsi terakhir yang dikembangkan pada Sprint 3 adalah fungsi untuk membagikan campaign dari aplikasi E-Initiative melalui media sosial. Fungsi ini dapat membagikan campaign pada semua media sosial yang ada dalam peranti pintar pengguna.

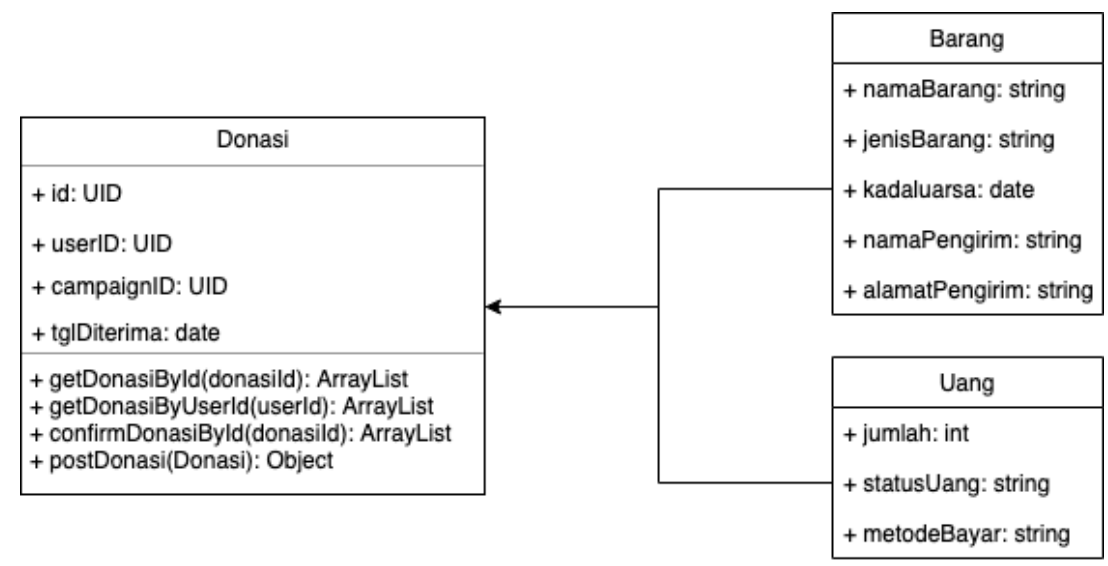

Gambar 6 Potongan class diagram melakukan donasi.
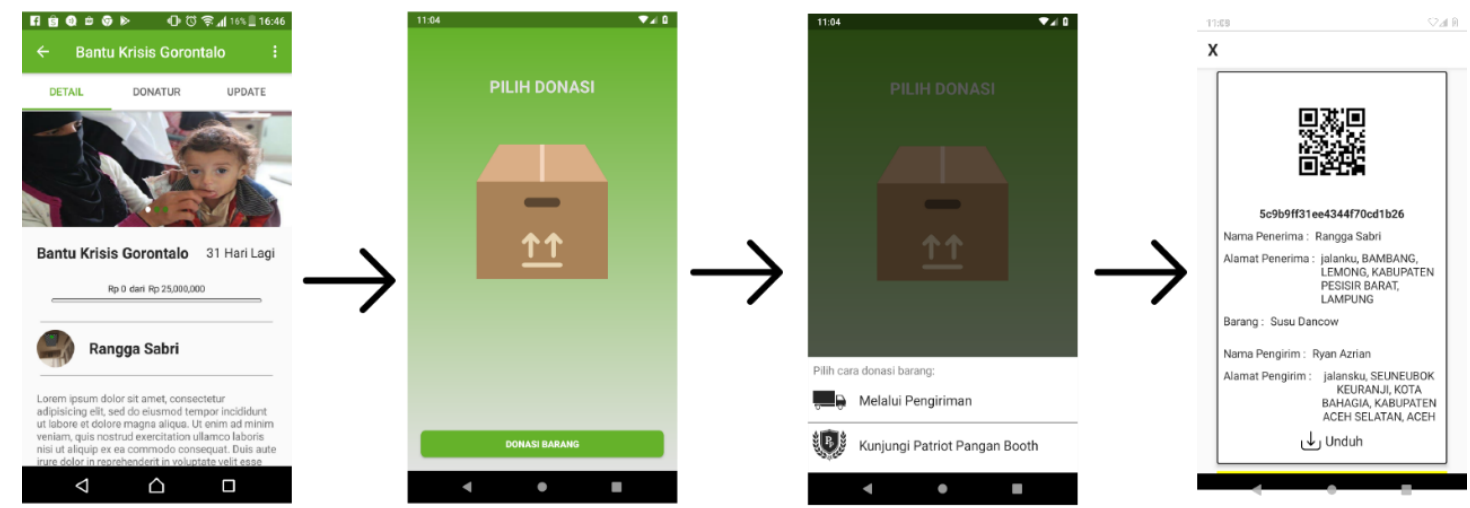

Gambar 7 Tampilan proses donasi barang.

\section{Sprint Review Meeting}

Dilakukan pengujian terhadap fungsi-fungsi yang telah dikembangkan pada sprint 3 menggunakan blackbox testing. Fungsi yang diuji meliputi fungsi donasi, lihat riwayat donasi dan bagi campaign. Dari hasil pengujian tersebut product owner menerima seluruh hasil pengujian sehingga tidak terdapat perubahan pada product backlog. 


\section{Sprint Retrospective}

Seluruh fungsi yang dikerjakan pada Sprint 3 telah berhasil dikerjakan. Banyaknya fungsi yang dikerjakan pada Sprint 3 sebanyak 3 fungsi. Sehingga tersisa sebanyak 4 items fungsi pada product backlog. Fungsi yang masih tersisa dalam product backlog akan dikerjakan pada sprint selanjutnya. Tidak terdapat masalah pada Sprint 3.

\section{Sprint 4 dan Sprint 5}

\section{Sprint Planning Meeting}

Sebelumnya tampilan detail campaign yang sudah diverifikasi hanya menampilkan informasi mengenai campaign tersebut. Namun product owner menginginkan adanya list donatur yang berpartisipasi pada campaign dan list update yang dilakukan oleh pemilik campaign. Sprint backlog yang terpilih pada Sprint 4 sebanyak 3 items dari product backlog yaitu fungsi list update campaign ke detail campaign, fungsi lihat donatur pada suatu campaign, dan fungsi menambahkan update campaign. Kemudian pada Sprint 5 dikembangkan fungsi realtime notification.

\section{Daily Scrum}

Pada Sprint 4 dikembangkan fungsi list update campaign berisi tentang update campaign yang dilakukan oleh pemilik campaign. Dalam list update campaign dapat berguna bagi donatur atau calon donatur untuk melihat sejauh mana donasi yang diberikan oleh para donatur disalurkan. Di sini pengguna dapat melihat keefektifan campaign yang dibuat. Sehingga menjadi salah satu pertimbangan bagi pengguna untuk melakukan donasi. Tampilan list campaign ditampilkan pada Gambar 8. Bentuk JSON list campaign yang didapatkan dari backend ditampilkan pada Gambar 9. Bentuk JSON ini diparsing di controller dan dimasukkan ke dalam model dan akan ditampilkan ke dalam XML, seperti yang ditampilkan pada potongan kode (Gambar 10). Fungsi kedua yang dikembangkan adalah fungsi list donatur. Fungsi ini berguna bagi para pengguna maupun pemilik campaign untuk melihat siapa saja yang menjadi donatur atau ikut berpartisipasi pada sebuah campaign. Fungsi terakhir yang dikembangkan pada Sprint 4 adalah fungsi menambahkan update campaign. Fungsi ini hanya bisa diakses oleh pemilik campaign pada campaign-nya. Pada fungsi ini pemilik campaign dapat memberikan progress sejauh mana telah menyalurkan donasi yang disumbangkan oleh para donatur.

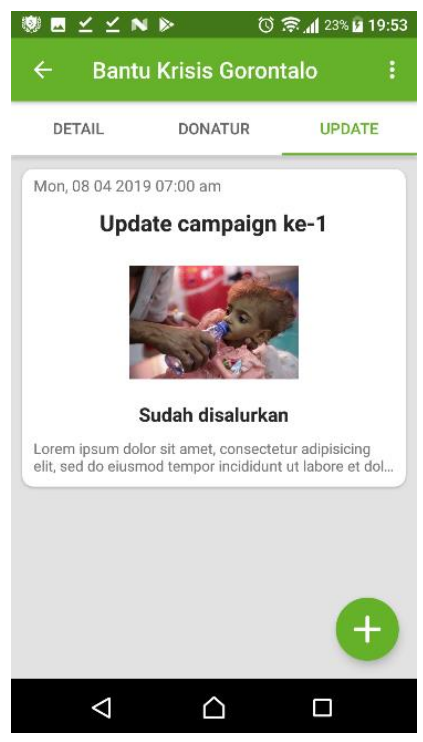

Gambar 8 Tampilan list campaign.

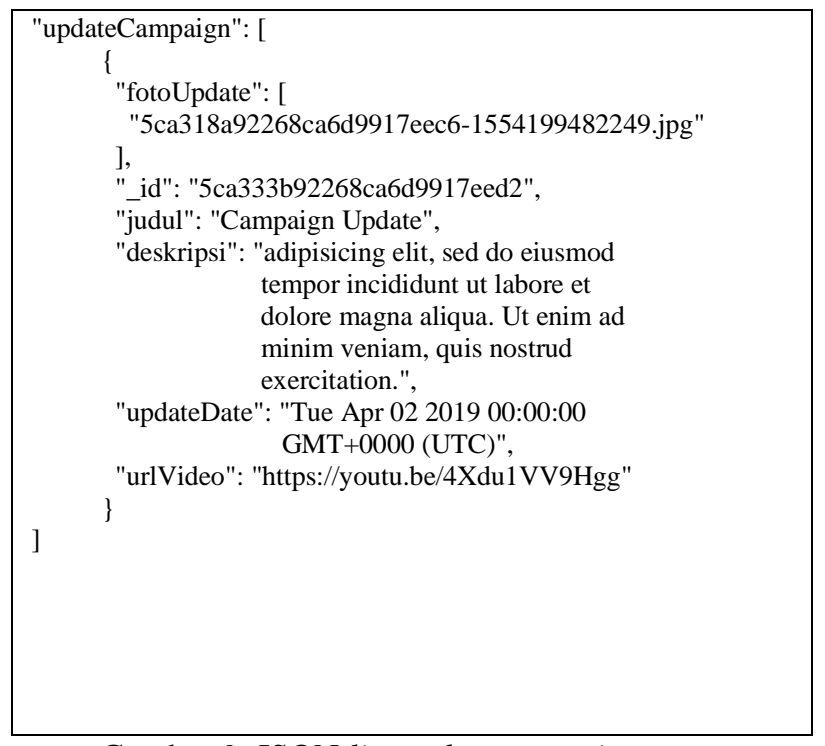

Gambar 9 JSON list update campaign.

Pada Sprint 5 dikembangkan fungsi realtime notification menggunakan third-party Socket.io. Sistem notifikasi bekerja dengan cara server/backend mengirimkan trigger kepada aplikasi mobile saat status campaign, donasi ataupun akun pengguna berubah. Perubahan ini 
dilakukan oleh admin dengan menggunakan API tertentu. Sementara itu aplikasi mobile terus melakukan listen terhadap notifikasi yang akan dikirimkan. Fungsi notifikasi akan bekerja bila pengguna mengaktifkan fitur tersebut pada halaman user profile.

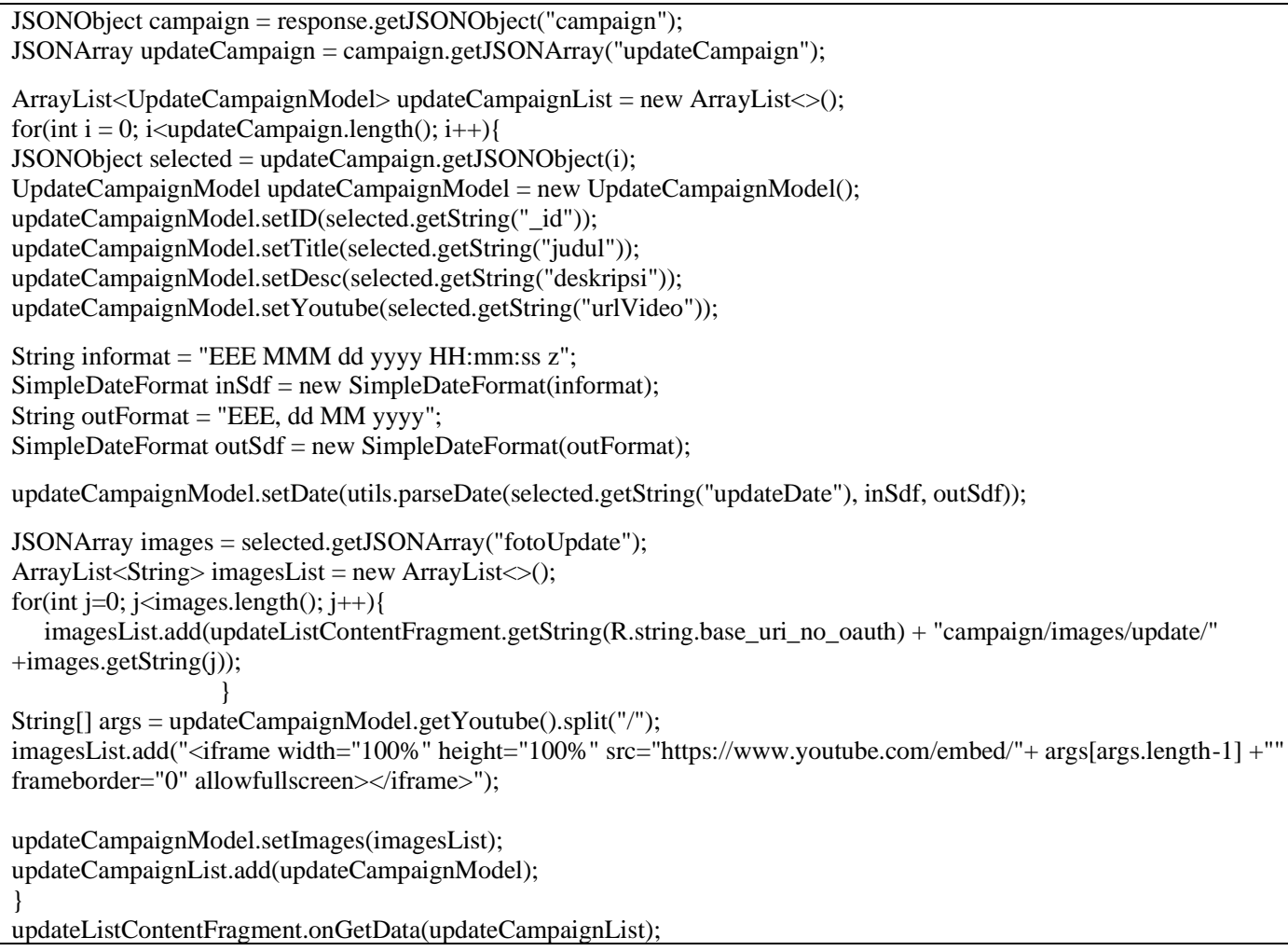

Gambar 10 Potongan parsing JSON to Model.

\section{Sprint Review Meeting}

Pada Sprint Review Meeting dilakukan pengujian menggunakan blackbox testing terhadap fungsi-fungsi yang telah berhasil dikembangkan selama Sprint 4 dan Sprint 5. Pengujian dilakukan terhadapa fungsi list update campaign, list donatur, tambah update campaign dan realtime notification. Pada tahapan ini juga didapatkan feedback dari product owner sebagai masukan bagi fungsi yang telah dikembangkan. Dari hasil pengujian tersebut product owner menerima seluruh hasil pengujian dan tidak ada perubahan pada product backlog.

\section{Sprint Retrospective}

Product owner menyampaikan fungsi-fungsi yang dianggap telah berhasil dikembangkan sesuai dengan keinginan product owner. Seluruh fungsi pada sprint backlog pada Sprint 4 dan Sprint 5 telah berhasil dikerjakan tanpa ada perubahan. Sehingga semua fungsi yang terdapat dalam product backlog telah berhasil dikembangkan. Tidak terdapat masalah pada Sprint 4 maupun pada Sprint 5.

\section{SIMPULAN}

Aplikasi E-Initiative Patriot Pangan berhasil dikembangkan dalam bentuk mobile apps Android menggunakan Android Studio. Dalam pengembangan aplikasi android E-Initative Patriot Pangan menggunakan metode Scrum dengan 5 sprint. Jumlah product backlog untuk mengembangkan aplikasi Android E-Initiative Patriot Pangan terdapat 19 items. Fungsi utama yang berhasil dikembangkan meliputi fungsi donasi barang/uang, membuat campaign, 
membagi campaign dan realtime notification menggunakan Socket.io. Aplikasi E-Initiative Patriot Pangan diharapkan berguna sebagai platform crowdfunding untuk membantu balita yang mengalami kekurangan gizi.

\section{DAFTAR PUSTAKA}

[AAPJI] Asosiasi Penyelenggara Jasa Internet Indonesia. 2017. Penetrasi dan Perilaku Pengguna Internet Indonesia 2017 [internet]. [diunduh 18 April 2019]. Tersedia pada: https://apjii.or.id/survei2017/download/pWiGqxI9zZuEK1NgwX0mAtsBDka8jf.

Alegre I, Moleskis M. 2016. Crowdfunding: a review and research agenda. SSRN Electronic Journal. 9-10.doi:10.2139/ssrn.2900921.

Asfarian A, Putra RP, Panatagama AP, Nurhadryani Y, Ramadhan DA. 2020. E-Initiative for Food Security: Design of Mobile Crowdfunding Platform to Reduce Food Insecurity in Indonesia. Di dalam: 2020 8th International Conference on Information and Communication Technology (ICoICT). Jun 24. Yogyakarta, Indonesia. Hlm 1-5. IEEE.

[BPS] Badan Pusat Statistik. 2018. Statistik Indonesia 2018 [internet]. [diunduh 22 April 2019]. Tersedia pada : https://www.bps.go.id/publication/download.html?nrbvfeve=NWE5 NjNjMWVhOWIwZmVkNjQ5N2QwODQ1\&xzmn=aHR0cHM6Ly93d3cuYnBzLmdv LmlkL3B1YmxpY2F0aW9uLzIwMTgvMDcvMDMvNWE5NjNjMWVhOWIwZmVk NjQ5N2QwODQ1L3N0YXRpc3Rpay1pbmRvbmVzaWEtMjAxOC5odG1s\&twoadfno arfeauf $=\mathrm{MjAxOS0wNC0yMiAyMTowMTo0NA \% 3D \% 3D.}$

Firdaus A. 2019. Pengembangan Back End Berbasis REST API pada Sistem EPartisipasi dan E-Inisiatif Patriot Pangan [skripsi]. Bogor (ID): Institut Pertanian Bogor.

[Kemenkes] Kementerian Kesehatan. 2018. Buku Saku Pemantauan Status Gizi Tahun 2017. Jakarta (ID): Kementerian Kesehatan.

Kickstarter. 2020. About. [Internet]. [diunduh 2020 November 14]. Tersedia pada: kickstarter.com/about.

Maulana F. 2019. Pengembangan Aplikasi Android Patriot Pangan Sebagai Sarana eParticipation Untuk Sistem Ketahanan Pangan Nasional [skripsi]. Bogor (ID): Institut Pertanian Bogor.

Massé M. 2012. REST API Design Rulebook. Sebastopol (US): O'Reilly.

Massolution. 2015. The crowdfunding industry report [internet]. [diunduh 2018 Des 4]. Tersedia pada: http://www.smv.gob.pe/Biblioteca/temp/catalogacion /C8789.pdf.

Panatagama AP. 2018. Food Patriot: A Real-Time Food Insecurity Early Warning System Based on Local Community E-Participation to Support Sustainable Development.The 18th International Students Summit on Food, Agriculture, and Environment in the New Century (ISS). Tokyo University of Agriculture, Jepang; 27-28 September 2018.

Panatagama AP, Nurhadryani Y, Asfarian A. 2019. Analysis and Design of Patriot Pangan: Towards Electronic Participation and Initiative Platform to Help Reduce Food Insecurity in Indonesia. Di dalam 2019 IEEE R10 Humanitarian Technology Conference (R10HTC) 2019 Nov 12. Depok, Indonesia. Hlm. 159-164. IEEE.

Prakoso MF. 2019. Implementasi Framework Vue Js pada Front-end Sistem Patriot Pangan Berbasis Web [skripsi]. Bogor (ID): Institut Pertanian Bogor.

Putra RP. 2020. Perancangan Pengalaman Pengguna Aplikasi E-Initiative Patriot Pangan Modul Crowdfunding [skripsi]. Bogor (ID): Institut Pertanian Bogor.

Pressman RS. 2010. Software Engineering: A Practitioner's Approach. Ed ke-7. New York(US): McGraw-Hill.

Ramadhan W. 2019. Pengembangan dan Optimasi Pangkalan data NoSql pada Sistem Patriot Pangan [skripsi]. Bogor (ID): Institut Pertanian Bogor.

Rising L, Janoff NS. 2000. The scrum software development process for small teams. IEEE Software. 17(4):26-32. 
Rosalina R, Handojo A, Wibowo A. 2015. Aplikasi crowdfunding sebagai perantara penggalangan dana berbasis website dan facebook application. Jurnal Infra. 3(2):303307.

Sachs JD. 2012. From millennium development goals to sustainable development goals. The Lancet. 379(9832):2206-2211.

Schwaber K, Sutherland J. 2017. The Scrum GuideTM. [Internet]. [diunduh 25 Desember 2018]. Tersedia pada: http://www.scrumguides.org/scrum-guide.html.

The Atlantic. 2012. Crowdfunding Nutrition: Using Kickstarter to Make Kids Healthier.

[Internet]. [diunduh 2020 November 14]. Tersedia pada: https://www.theatlantic.com/health/ archive/2012/06/crowdfunding-nutrition-using-kickstarter-to-make-kids-healthier/258 478/.

Veit M, Hermann S. 2003. Model-view-controller and Object teams: a perfect match of paradigms. The $2^{\text {nd }}$ International Conference on a Aspect-oriented Software. Boston, Massachusetts; 17-21 Maret 2003. 